\title{
Separation of thoracopagus-cardiopagus twins joined by a myocardial bridge
}

Louis C. Benjamin, MD, a Jai Nahar, MD, ${ }^{\mathrm{b}}$ Craig Sable, MD, ${ }^{\mathrm{b}}$

Frank M. Midgley, MD, ${ }^{c}$ and Gregory B. Di Russo, MD, ${ }^{c}$

Pittsburgh, $\mathrm{Pa}$, and Washington, DC

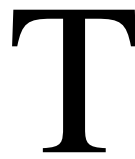

horcopagus twins often have complex cardiac anomalies associated with other congenital defects. ${ }^{1}$ This has precluded successful separation in the past.

We report a case in which a very small connecting bridge of myocardial tissue resulted in one ventricle pacing the other in thoracopagus-cardiopagus twins. This defect was not noted before the operation, despite extensive imaging. Surgical division and subsequent independent QRS complexes seen after separation of the myocardial bridge as in our case has not previously been reported.

\section{Clinical Summary}

Four-month-old infants born as conjoined twins were delivered at 34 weeks' gestational age by cesarean section. They were known to have a shared liver and were connected at the abdominal and thoracic cavities.

Cardiac evaluation included electrocardiography, echocardiography, cardiac catheterization, magnetic resonance imaging, and computed tomographic scanning. Both hearts were in the same pericardial sac but appeared structurally normal. The left ventricle of one twin was found to protrude into the thoracic cavity of the other, in direct contact with the other twin's right atrium and right ventricle. However, no communications or shared myocardial tissue between the twins' hearts could be visualized on any of the preoperative testing. Preoperative angiography demonstrated no shared coronary vessels according to the sequential and simultaneous aortic root angiograms, which clearly delineated the normal coronary arteries of each heart.

The twins were noted to have synchronous cardiac rhythms, despite the apparent absence of an anatomic source for shared conduction tissue. The preoperative tracing showing synchronous electrocardiographic activity between the twins is shown in Figure 1, A.

\footnotetext{
From the Division of Cardiac Surgery, University of Pittsburgh Medical Center, Pittsburgh, PA, and the Division of Cardiology ${ }^{\mathrm{b}}$ and Department of Pediatric Cardiac Surgery, ${ }^{\mathrm{c}}$ Children's National Medical Center, Washington, DC.

Received for publication April 13, 2005; accepted for publication April 21, 2005 .

Address for reprints: Louis C. Benjamin, MD, Division of Cardiac Surgery, University of Pittsburgh Medical Center, Pittsburgh, PA 15213 (E-mail: 1cbenjamin03@comcast.net).

J Thorac Cardiovasc Surg 2005;130:1212-3

$0022-5223 / \$ 30.00$

Copyright (C) 2005 by The American Association for Thoracic Surgery doi:10.1016/j.jtcvs.2005.04.034
}

At exploration, after division of the lateral aspect of the skin bridge between the twins, the pericardium was opened. The hearts were beating synchronously with excellent function. A band of muscle and fatty tissue ap-

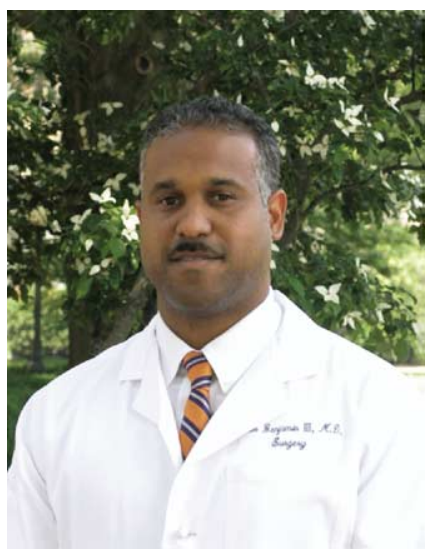

Dr Benjamin proximately $4 \mathrm{~mm}$ in diameter and $4 \mathrm{~mm}$ in length connected the two hearts.

The communication arose at the base of one left ventricle, adjacent to the origin of the posterior descending coronary artery. On the other heart, it attached near the atrioventricular groove, close to the right coronary artery. After test occlusion of the connection with a Dacron polyester tie and a tourniquet, two pledgeted sutures were placed, one at the base of each end of the myocardial bridge, and the tissue was divided. After separation, the two hearts immediately began to beat in an asynchronous fashion, in sinus rhythm, without any signs of arrhythmia. This is illustrated by the electrocardiographic tracings shown in Figure 1, $B$.

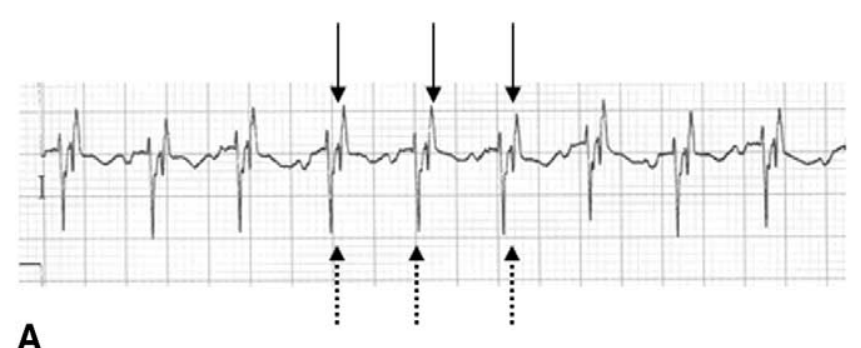

A

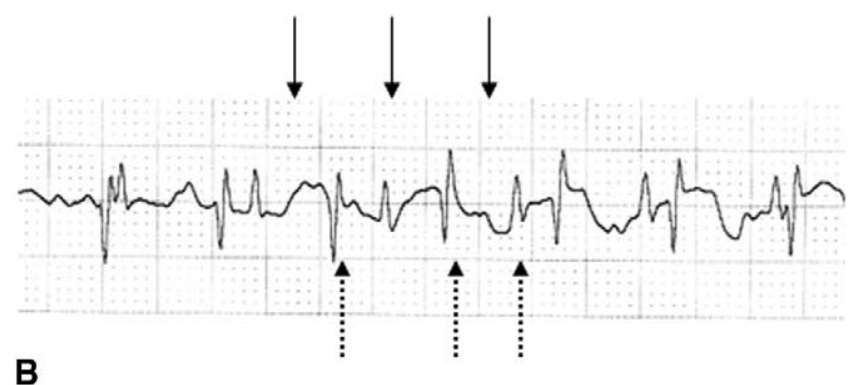

Figure 1. A, Preoperative electrocardiogram showing tracing from one twin with consistent ventricular activity from both twins (solid and broken arrows) in a one-to-one and fixed relationship. B, Postoperative electrocardiographic rhythms immediately after myocardial bridge was ligated (before physical separation of twins), showing dissociation of ventricular activity (solid and broken arrows), with normal heart rates in both twins. 


\section{Discussion}

The twins described in this case had no radiologic evidence of a congenital anomaly, despite exhaustive testing. The fact that the cardiac rhythms were synchronous was cause for concern, because synchronous heart rhythms in thoracopagus twins have been shown to be consistent with shared cardiac chambers. ${ }^{2,3}$ An electrocardiogram demonstrating independent QRS complexes suggests isolated ventricles. We could not find any case in the literature where there was an isolated myocardial bridge that could be separated.

Although the ability of individual myocytes to sustain an electrical potential and go through the cardiac cycle has been well described, the ability of shared myocardial tissue to propagate a rhythm between two individual hearts has not. The potential for heart block or other fatal arrhythmias was entertained, because we could not predict the electrophysiologic consequences of separating this tissue. Since the operation, the children have shown no cardiac abnormalities and have remained in sinus rhythm.

\section{References}

1. Patel R, Fox K, Dawson J, Taylor JF, Graham GR. Cardiovascular anomalies in thoracopagus twins and the importance of preoperative cardiac evaluation. Br Heart J. 1977;39:1254-8.

2. Sanders SP, Chin AJ, Parness IA, Benacerraf B, Greene MF, Epstein $\mathrm{MF}$, et al. Prenatal diagnosis of congenital heart defects in thoracoabdominally conjoined twins. $N$ Engl J Med. 1985;313:370-4.

3. Wu MH, Lai YC, Lo HM, Hsu YH, Lue HC. Assessment of electromyocardial continuity in conjoined (thoracopagus) twins. Am J Cardiol. 1992;69:830-2.

\title{
Thoracoscopic removal of a knife impaled in the chest
}

\author{
Joshua H. Burack, MD, Emmanuel A. Amulraj, MD, Patricia O'Neill, MD, Gregory Brevetti, MD, and \\ Robert C. Lowery, MD, Brooklyn, NY
}

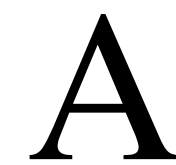

s surgeons become more comfortable with the technique, video-assisted thoracoscopic surgery (VATS) has evolved to provide both diagnostic and therapeutic value in increasingly complex cases of thoracic trauma. We report a case in which VATS techniques were used to remove a large knife impaled in the left side of the chest and to manage a concomitant injury to the left lower lobe of the lung.

\section{Clinical Summary}

A 25-year-old man was involved in an altercation and sustained a single stab wound to the left paraspinous region, midway between the tip of the scapula and the spine. The knife remained in situ, with only a large handle visible (Figure 1). The patient was transported by ambulance in the prone position and had stable vital signs on arrival to the emergency department. Examination was remarkable only for slightly decreased breath sounds on the left side, and the patient continued to have stable cardiopulmonary function. A chest radiograph confirmed the intrathoracic position of the knife at the seventh thoracic vertebra (Figure 2).

\footnotetext{
From the Department of Surgery, Chest Surgical Service, Kings County Hospital Center, Brooklyn, NY.

Received for publication April 19, 2005; accepted for publication May 20, 2005.

Address for reprints: Joshua Burack, MD, Department of Surgery, Box 40, State University of New York-Downstate, 450 Clarkson Ave, Brooklyn, NY 11203 (E-mail: jburack@ downstate.edu).

J Thorac Cardiovasc Surg 2005;130:1213-4

$0022-5223 / \$ 30.00$

Copyright $\odot 2005$ by The American Association for Thoracic Surgery doi:10.1016/j.jtcvs.2005.05.050
}

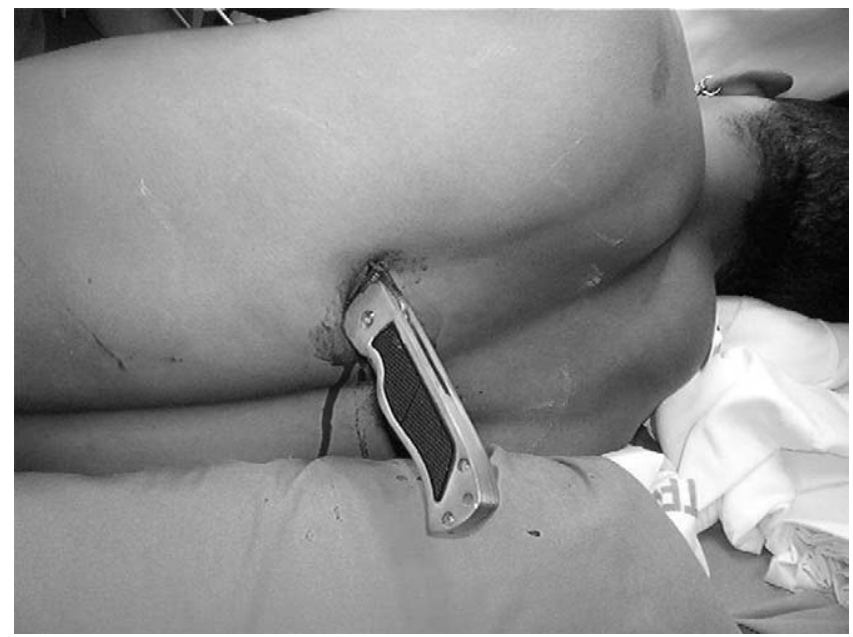

Figure 1. Large knife impaled in the posterior left chest.

Sixty minutes after the injury, the patient was anesthetized in the operating room with a double-lumen endotracheal tube. With the patient in the right lateral decubitus position, three separate 2 -cm thoracoscopic incisions were created in the left side of the chest: two in the fifth intercostal space and the anterior and posterior axillary lines and a third camera incision in the seventh intercostal space and the midaxillary line. On exploration, $700 \mathrm{~mL}$ of blood and clot was evacuated from the posterior pleural cavity, and no mediastinal hematoma was present. An 8-cm segment of knife blade was visible in the chest, just lateral to the middescending thoracic aorta, with a posterolateral tract toward the left lower lobe of the lung. A through-and-through injury of the 